\title{
Molecular and pathogenetic aspects of tumor budding in colorectal cancer
}

\author{
Heather Dawson ${ }^{1,2}$ and Alessandro Lugli ${ }^{1,2}$ \\ ' Clinical Pathology Division, Institute of Pathology, University of Bern, Bern, Switzerland \\ 2 Translational Research Unit, Institute of Pathology, University of Bern, Bern, Switzerland
}

\section{Edited by:}

Luigi M. Terracciano, University

Hospital Basel, Switzerland

\section{Reviewed by:}

Pierlorenzo Pallante, Consiglio Nazionale delle Ricerche (CNR), Italy Venancio Avancini Alves, University of Sao Paulo School of Medicine, Brazil

\section{${ }^{*}$ Correspondence:}

Heather Dawson, Clinical Pathology Division, Institute of Pathology,

University of Bern, Murtenstrasse 31, Bern 3010, Switzerland

e-mail: heather.dawson@pathology. unibe.ch
In recent years, tumor budding in colorectal cancer has gained much attention as an indicator of lymph node metastasis, distant metastatic disease, local recurrence, worse overall and disease-free survival, and as an independent prognostic factor. Tumor buds, defined as the presence of single tumor cells or small clusters of up to five tumor cells at the peritumoral invasive front (peritumoral buds) or within the main tumor body (intratumoral buds), are thought to represent the morphological correlate of cancer cells having undergone epithelial-mesenchymal transition (EMT), an important mechanism for the progression of epithelial cancers. In contrast to their undisputed prognostic power and potential to influence clinical management, our current understanding of the biological background of tumor buds is less established. Most studies examining tumor buds have attempted to recapitulate findings of mechanistic EMT studies using immunohistochemical markers. The aim of this review is to provide a comprehensive summary of studies examining protein expression profiles of tumor buds and to illustrate the molecular pathways and crosstalk involved in their formation and maintenance.

Keywords: tumor budding, colorectal cancer, immunohistochemistry, EMT, tumor microenvironment, immunohistochemistry

\section{INTRODUCTION}

The hallmark of malignant disease, namely the ability of a tumor to disseminate and colonize distant sites, requires an arsenal of cellular characteristics. In colorectal cancer and a growing number of solid tumors, epithelial-mesenchymal transition (EMT) is proposed as a fundamental mechanism for epithelial cells to acquire such a "malignant" phenotype $(1,2)$. Tumor buds, defined as the presence of single tumor cells or small groups of up to five tumor cells at the invasive tumor front or within the main tumor body [termed intratumoral buds (3)] are thought to be the histomorphological correlate of cells to undergo EMT in colorectal cancer. Indeed, high-grade tumor budding is strongly and independently associated with many adverse features such as vascular invasion, lymph node, and distant metastases and is detrimental to overall and disease-free survival (4-12).

From a morphological point of view, tumor buds tend to appear more atypical than their counterparts in the main tumor body [hence the previous term "tumor dedifferentiation" (13)] Tumor buds may be difficult to detect on H\&E stained slides, as they are, per definition, single tumor cells or small clusters of tumor cells that have broken off from the main tumor body and "blend" into the tumor microenvironment, often obscured by peritumoral inflammatory reaction. At high power, it may be difficult to distinguish tumor buds from reactive stromal cells, which may also appear large and atypical. Pancytokeratin immunostains are of great help in the accurate identification of tumor buds (Figures 1A,B), and have been demonstrated to significantly improve interobserver agreement in tumor bud assessments (14).

As tumor buds are visualized in a histological "snapshot," studies using immunohistochemistry have been pivotal in improving our understanding of tumor buds and their protein expression profiles (15). A distinct heterogeneity in immunohistochemical expression profiles among different tumor compartments (center vs. invasive front and tumor buds) has contributed to our appreciation of the consequences of EMT (15).

\section{MOLECULAR BACKGROUND OF TUMOR-BUDDING PHENOTYPES}

It is well-recognized that "colorectal cancer" encompasses fundamentally different molecular phenotypes following various pathways of carcinogenesis (16). As a consequence, colorectal cancers arising from different pathways differ in terms of biological behavior, histomorphological features, and protein expression $(17,18)$. One of the major and most well-studied pathways involves mutation of the APC gene, activating the WNT/wingless signaling pathway. Its major downstream effectors, $\beta$-catenin, and E-cadherin, are considered integral components of EMT (1). Therefore, it is not surprising that high-grade tumor budding is strongly associated with tumors arising from the tumors with mutation of the APC gene (19). In contrast, tumors with microsatellite instability, another well-studied pathway of colorectal carcinogenesis, are inversely correlated with tumor budding $(19,20)$. To date, only few studies have systematically assessed differences in tumor bud expression profiles taking into account the molecular background of tumors. In MMR-deficient tumors, reduced $\beta$-catenin expression in tumor buds was demonstrated in comparison to MMR-proficient tumors (21), leading to the speculation that mechanisms other than only Wnt signaling may lead to the formation of tumor buds in MMR-deficient cancers. Also, buds arising in MMR-deficient tumors may represent a less aggressive budding 
phenotype, highlighted by reduced expression of the cell locomotion protein laminin $5 \gamma 2$ in buds and in line with the generally milder clinical course of these tumors (21). On the other hand, adenocarcinomas with "serrated" morphology, which did not display histological features associated with microsatellite instability, were shown to have increased expression of laminin $5 \gamma 2$ and decreased expression of nuclear $\beta$-catenin and E-cadherin in tumor-budding cells compared to matched "conventional" adenocarcinomas (22). Unfortunately, the classification of these tumors was made based on morphology alone, hence their true molecular background remains presumptive [serrated morphology without features of MSI-high tumors being most suggestive of BRAFmutated, CIMP-high, MMR-proficient tumors, which are known to behave aggressively $(23,24)]$.

\section{Wnt SIGNALING}

Activation of WNT signaling leads to stabilization of membranous/cytoplamasmic $\beta$-catenin and its translocation to the nucleus. Located at the cell membrane, $\beta$-catenin complexes with E-cadherin and is crucial for maintaining cell-cell adhesion and epithelial cell polarity (24). However, mutations in the APC gene lead to nuclear translocation of $\beta$-catenin, where it binds to members of the Tcf/LEF family, and functions as an oncogenic transcription factor. Therefore, preservation of membranous Ecadherin and $\beta$-catenin are indicative of an epithelial phenotype, whereas loss of E-Cadherin and nuclear expression of $\beta$-catenin are considered hallmarks of EMT. Due to their well-established role in EMT, $\beta$-catenin and its transcriptional targets represent the most extensively studied group of proteins in tumor buds. Increased nuclear expression of $\beta$-catenin in tumor buds in comparison to the main tumor body has been demonstrated in several studies $(21,22,25-29)$ as has loss of E-Cadherin $(4,28,30,31)$ (summarized in Table 1). However, canonical Wnt signaling and $\beta$-catenin alone appear not to be the sole driving force behind tumor budding, as nuclear $\beta$-catenin at the invasive tumor front did not necessarily predict budding $(32,33)$ and although up to $90 \%$ of all colorectal cancers have dysregulation of Wnt signaling and 60\% harbor APC mutations (34), high-grade budding is only seen in a proportion of these (around 40\%), depending on case mix and evaluation methods $(9,14,35-37)$.

The functions of proteins encoded by WNT target genes confer characteristics of a malignant mesenchymal phenotype. Proteins involved in the degradation of the extracellular matrix, such as MMP-9 and Cathepsin B have been shown to be overexpressed in buds (38). Several studies have demonstrated expression of the cell locomotion protein laminin $5 \gamma 2$ in buds $(21,22,39,40)$.

Other cell adhesion proteins such as EpCAM have been implicated in the budding process, with loss of membranous expression identified in tumor buds (25). EpCAM is activated by proteolysis by tumor-necrosis factor alpha (TNF $\alpha$ ) converting enzyme, resulting in release of EpICD into the cytoplasm, which becomes part of the h-catenin and LEF transcriptional complex (41). The neuronal cell adhesion molecule L1 has also been identified as a $\beta$-catenin target gene and is preferentially expressed in tumor buds where it is co-regulated with ADAM10, a metalloprotease involved in cleaving and shedding L1s extracellular domain (42). L1 has recently been demonstrated to induce NFKB signaling in colorectal cancer cells (52), NFאB being implicated in EMT (53). These studies demonstrate the degree of crosstalk between Wnt signaling and EMT.

Modulators of Wnt signaling have also been detected in tumor buds, such as the AAA + protein family member pontin (29), which has been implicated in enhancing the effect of Wnt signaling by binding to the $\beta$-catenin/LEF complex.

\section{TUMOR BUDS, EMT, AND "STEMNESS"}

The stem-cell concept is centered on the notion that tumor progression is driven by a primarily undifferentiated population of tumor-initiating cancer cells. After initially being described in acute myeloid cancers, cancer stem cells (CSCs) have been identified in a myriad of solid tumors including colorectal cancers. CSCs display aggressive features such as increased invasiveness, chemoresistance, and the ability to mediate angiogenesis and resist apoptosis, with the ability to re-differentiate at metastatic sites (54). It would therefore stand to reason that tumor buds may represent a population of migrating CSCs (55). Indeed, there is increasing evidence linking CSCs to EMT. For instance, forced expression of the EMT transcription factor snail in CRC cell lines leads to increased expression of the putative stem-cell markers CD133 and CD44 (43). Alleged stem-cell markers in colorectal cancer include EpCAM (alongside its role as a cell adhesion molecule), CD133, CD44, ABCG5, CD90, CD24, CD166, LGR5 (a Wnt pathway target), and ALDH1 (49). Several studies have examined the immunohistochemical expression of stem-cell markers in different compartments of colorectal cancer. CD133 has been reported to be preferentially expressed at the invasive tumor front but not within tumor buds themselves (44). Hostettler et al. (49) found expression of CD133, 166, CD44, and CD90 to be a rare event in tumor buds, but cytoplasmic EpCAM and ABGC5 were frequently expressed in tumor-budding cells. Both of these markers were demonstrated to have a negative effect on survival, and expression of ABCG5 in buds was associated with worse prognosis in node-negative colorectal cancer patients. A study examining the expression of Lgr5 found a small subset of buds to be positive for this putative stem-cell maker but 6- to 11.5-fold higher expression rates in distant metastases were detected (56). Taken together, the above results support the notion that expression of stem-cell markers appears to be heterogeneous among buds and that only small populations of tumor cells (low-frequency subclones) may be perpetrators of metastatic disease.

\section{CELL CYCLE-RELATED PROTEINS}

There is accumulating evidence indicating that the driving force of colorectal cancer progression may not be attributable to tumor cell proliferation alone. Generally, it is thought that EMT-derived tumor cells are hypo-proliferative, underlining the significance of aggressive cellular machinery to exert their malignant properties (57). The cell cycle regulators cyclin D1 and p16 are Wnt signaling targets and their activation is a suggested mechanism of EMTinduced growth arrest. Under normal circumstances, nuclear p16 is a direct inhibitor of cyclin D1, arresting the cell cycle. However, located in the cytoplasm, p16 is thought to bind with CDK4, blocking its transport to the nucleus. CDK4 is required for cyclin D1 activation. Therefore, in the absence of CDK4, cyclin D1 forms an 
Table 1 | Summary of studies examining tumor buds by immunohistochemistry

\begin{tabular}{|c|c|c|c|c|c|}
\hline Biological role & Reference & Markers and methods & Cohort & $\begin{array}{l}\text { Budding } \\
\text { systematically } \\
\text { assessed? } \\
\text { Scoring method } \\
\text { (reference) }\end{array}$ & Results/relevance \\
\hline Wnt signaling & Gosens (25) & $\begin{array}{l}\text { EpCAM: three different antibodies } \\
\text { (Ber-EP4, 311-1K1 and a polyclonal } \\
\text { antibody), double staining for } \\
\beta \text {-catenin and Ep-CAM. mRNA in situ } \\
\text { hybridization of Ep-CAM, WTS }\end{array}$ & $\begin{array}{l}133 \text { rectal cancers (Dutch } \\
\text { RT + TME trial), Stage II-IV }\end{array}$ & Yes (Ueno) (9) & $\begin{array}{l}\text { Tumor buds showed lack of membranous and } \\
\text { increased cytoplasmic Ep-CAM staining and } \\
\text { nuclear expression of } \beta \text {-catenin. Reduced } \\
\text { Ep-CAM staining at the invasive margins } \\
\text { correlated with tumor-budding, grade, and } \\
\text { increased risk of LR }\end{array}$ \\
\hline Wnt signaling & Brabletz (27) & $\beta$-catenin, WTS & 44 Stage I-III CRC & No & $\begin{array}{l}\text { Expression of nuclear } \beta \text {-catenin in } 54 \% \text { of all } \\
\text { cases. Strong nuclear staining predominantly at } \\
\text { tumor front }(80-100 \%) \text { with strongest staining in } \\
\text { tumor buds. Tumor center often without nuclear } \\
\text { staining but with retained membranous staining }\end{array}$ \\
\hline Wnt signaling & El-Bahrawy (28) & $\begin{array}{l}\text { E-Cadherin, } \alpha \text {-, } \beta \text {-, and } \gamma \text {-catenin (each } \\
\text { immunohistochemistry and mRNA), } \\
\text { WTS }\end{array}$ & 30 Dukes A-C CRC & No & $\begin{array}{l}\text { Cytoplasmic accumulation of E-cadherin and } \\
\text { catenins in over } 80 \% \text { of cases. Increased staining } \\
\text { of } \beta \text {-catenin toward tumor front }\end{array}$ \\
\hline Wnt signaling & Lauscher (29) & $\begin{array}{l}\text { Pontin, } \beta \text {-catenin, WTS. Pontin } \\
\text { western blot on six cases }\end{array}$ & 34 CRC Stage I-IV & No & $\begin{array}{l}\text { Cytoplasmic pontin expression in all cases, } \\
\text { additional nuclear positivity in } 50 \% \text { of cases. } \\
\text { Nuclear pontin correlated with nuclear } \beta \text {-catenin } \\
\text { in all cases. Nuclear pontin staining stronger at } \\
\text { invasive margin and tumor buds in comparison to } \\
\text { tumor center ( } 41.2 \text { and } 37.9 \% \text { of cases). Sample } \\
\text { size insufficient for significant correlation to stage }\end{array}$ \\
\hline Wnt signaling & Garcia-Solano (22) & $\begin{array}{l}\beta \text {-catenin, e-cadherin, } \mathrm{p} \text {-cadherin, } \\
\text { laminin5 } 22 \text {, SMAD4, WTS }\end{array}$ & $\begin{array}{l}20 \text { SAC (defined by } \\
\text { histomorphologic criteria, no } \\
\text { features of MSI-high tumors) with } \\
\text { stage matched } 20 \text { CAC }\end{array}$ & Yes (Ueno) & $\begin{array}{l}\text { Increased expression of laminin } 5 \gamma 2 \text {, decreased } \\
\text { expression of nuclear } \beta \text {-catenin and membranous } \\
\text { e-cadherin in tumor buds of SAC in comparison } \\
\text { to CAC }\end{array}$ \\
\hline Wnt signaling & Shinto (21) & $\begin{array}{l}\text { laminin5 } 2 \text {, } \beta \text {-catenin (assessed in } \\
\text { tumor buds), MUC2, MUC5AC } \\
\text { (assessed on entire tumor), WTS. } \\
\text { Laminin5 } 2 \text { promoter methylation }\end{array}$ & $\begin{array}{l}80 \text { CRC with high-grade budding: } \\
9 \text { sporadic MMR-deficient, } 7 \text { Lynch } \\
\text { MMR-deficient and } 64 \text { sporadic } \\
\text { MMR-proficient, Stage n/a }\end{array}$ & Yes (Ueno) & $\begin{array}{l}3 / 9 \text { sporadic MMRd laminin5 } \gamma 2 \text { compared to } \\
46 / 64 \text { sporadic MMRp ( } p 0.05 \text { ) and } 2 / 7 \text { Lynch } \\
\text { ( } p=0.03 \text { ). Nuclear } \beta \text {-catenin more frequent in } \\
\text { MMRp than MMRd cancers ( } p 0.01 \text { ). No } \\
\text { difference in methylation among subsets but } \\
\text { correlation between methylation and negative } \\
\text { laminin5 } \gamma 2\end{array}$ \\
\hline
\end{tabular}




\begin{tabular}{|c|c|c|c|c|c|}
\hline Biological role & Reference & Markers and methods & Cohort & $\begin{array}{l}\text { Budding } \\
\text { systematically } \\
\text { assessed? } \\
\text { Scoring method } \\
\text { (reference) }\end{array}$ & Results/relevance \\
\hline $\begin{array}{l}\text { Cell differentiation } \\
\text { cell cycle }\end{array}$ & Harbaum (30) & $\begin{array}{l}\text { CK7, CK20, E-cadherin, MUC2, and } \\
\text { MIB1. CK7: } 370 \text { cancers on } \\
\text { multi-punch TMA, CK7 positive cases } \\
\text { re-evaluated on WTS with all markers }\end{array}$ & 370 CRC Stage I-IV & Yes (Ueno) & $\begin{array}{l}32 \text { cases positive for CK7. CK7 positivity prevailed } \\
\text { in tumor buds, these cells were positive for CK20 } \\
\text { and negative for E-Cadherin, MUC2 and MIB1 on } \\
\text { serial sections. Raises the notion of "EET" } \\
\text { (epithelial-epithelial transition) }\end{array}$ \\
\hline Wnt signaling & Brabletz (31) & $\begin{array}{l}\text { CK18, } \beta \text {-catenin, e-cadherin, Ki-67, } \\
\text { WTS }\end{array}$ & 72 CRC Stage n/a & No & $\begin{array}{l}\text { Nuclear } \beta \text { catenin in tumor buds accompanied by } \\
\text { reduced E-cadherin and Ki- } 67 \text { reactivity, inverse } \\
\text { immunoprofile in main tumor and metastases }\end{array}$ \\
\hline Wnt signaling & Horkko (32) & $\begin{array}{l}\text { Tumor-budding margin on all cases, } \\
\beta \text {-catenin (108 cases), MNF116 ( } 53 \\
\text { cases to assess separately for } \\
\text { budding), WTS }\end{array}$ & 466 CRC Dukes A-D & Yes (Ueno) & $\begin{array}{l}\text { Nuclear } \beta \text { catenin increased at invasive front and } \\
\text { in tumor buds, but no correlation between } \\
\text { expression presence/absence of budding }\end{array}$ \\
\hline Wnt signaling & $\begin{array}{l}\text { Guzinska- } \\
\text { Ustymowicz (38) }\end{array}$ & MMP-9 and cathepsin B, WTS & 55 pT3 G2 CRC & Yes (Morodomi) (37) & $\begin{array}{l}\text { Expression of MMP-9 and Cathepsin B associated } \\
\text { with lymph node involvement }(p<0.01)\end{array}$ \\
\hline Wnt signaling & Rubio (39) & MNF116, Ki-67, laminin5 & $\begin{array}{l}6 \text { CRC (preliminary report), Stage } \\
\text { n/a }\end{array}$ & Hotspot on HE & $\begin{array}{l}\text { Mean positivity of buds in comparative fields: } \\
\text { MNF 116: } 86.2, \text { Ki-67: } 9.7 \text {, laminin5: } 9.3\end{array}$ \\
\hline Wnt signaling & Gavert (42) & $\beta$-catenin, L1, ADAM10, WTS & $25 \mathrm{CRC}$, Stage n/a & No & $\begin{array}{l}\text { L1 not detected in main tumor body, but at } \\
\text { invasive front and tumor buds, co-localization with } \\
\text { ADAM10, and nuclear } \beta \text {-catenin }\end{array}$ \\
\hline Wnt signaling & Gavert (52) & NFKB, L1, ezrin, WTS & $25 \mathrm{CRC}$, Stage n/a & No & $\begin{array}{l}\text { Tumor buds co-express ezrin, nuclear NfKb and } \\
\mathrm{L1} \text {, central tumor regions with relative lack } \\
\text { immunoreactivity. Together with functional data } \\
\text { supports hypothesis that L1-mediated activation } \\
\text { of NFKB signaling is a major route of CRC tumor } \\
\text { progression }\end{array}$ \\
\hline $\mathrm{CSC}$ & Hostettler (49) & $\begin{array}{l}\text { CK22, CD133, CD166, CD24, CD44s, } \\
\text { CD90, EpCAM, ALDH1, ABCG5, } \\
\text { evaluation within tumor buds on WTS }\end{array}$ & $\begin{array}{l}101 \text { cases with densest budding } \\
\text { out of cohort with } 300 \mathrm{CRC} \\
\text { patients, Stage n/a }\end{array}$ & Yes (Ueno) & $\begin{array}{l}\text { CD90, CD44s, and CD133 infrequent in buds } \\
(<5 \%) . A L D H 1, C D 24 \text { and CD166 in 16.5, 16.2, } \\
\text { and } 34 \% . A B C G 5 \text { and EpCAM in } 35 \text { and } 69 \% \text { of } \\
\text { cases. EpCAM and ABCG5 in buds significantly } \\
\text { associated with worse prognosis, especially in } \\
\text { node-negative patients with ABCG5 positive buds }\end{array}$ \\
\hline
\end{tabular}


Table 1 | Continued

\begin{tabular}{|c|c|c|c|c|c|}
\hline Biological role & Reference & Markers and methods & Cohort & $\begin{array}{l}\text { Budding } \\
\text { systematically } \\
\text { assessed? } \\
\text { Scoring method } \\
\text { (reference) }\end{array}$ & Results/relevance \\
\hline $\csc$ & Kleist (56) & Lgr5, WTS & $\begin{array}{l}89 \text { cases Stage I-IV, additional } \\
\text { distant metastases from } 31 \\
\text { patients }\end{array}$ & Yes (Prall) (36) & $\begin{array}{l}12.9 \% \text { of cases had Lgr5 positive buds, distant } \\
\text { metastases from these cases had } 6 \text { - to } 11.5 \text {-fold } \\
\text { higher expression rates }\end{array}$ \\
\hline Cell cycle & Dawson (59) & $\begin{array}{l}\text { Ki-67 (WTS), Caspase3, } \\
\text { M30Cytodeath (multi-punch TMA) }\end{array}$ & 188 Stage I-IV CRC & $\begin{array}{l}\text { Yes (Karamitopoulou) } \\
\text { (35) }\end{array}$ & $\begin{array}{l}\text { Ki-67 expression in } 0.3 \% \text { of buds, in } 35 \% \text { tumor } \\
\text { center ( } p \text { 0.0001). Caspase- } 3 \text { comparatively lower } \\
\text { in tumor buds than other compartments ( } p \\
0.0001) \text {. Rare cases with Ki-67 and caspase } 3 \\
\text { immunoreactivity associated with poorer } \\
\text { prognosis }\end{array}$ \\
\hline RAS/RAF & Koelzer (67) & $\begin{array}{l}\text { RKIP, NFkB, E-Cadherin WTS RKIP, } \\
\text { matched NFKB, and E-Cadherin on } \\
\text { multi-punch TMA }\end{array}$ & 178 Stage I-IV CRC & Yes (Karamitopoulou) & $\begin{array}{l}0.9 \% \text { of tumor buds positive for RKIP, but } \\
\text { expression in main tumor body rather than buds } \\
\text { predictive for metastatic disease, vascular } \\
\text { invasion, budding, and invasive tumor border } \\
\text { configuration. RKIP expression correlated with } \\
\text { NFkB expression }\end{array}$ \\
\hline RAS/MAPK & Dawson (68) & TrkB, multi-punch TMA & 211 Stage I-IV CRC & Yes (Karamitopoulou) & $\begin{array}{l}\text { Trkb }(\mathrm{m}) \text { overexpressed in buds in comparison to } \\
\text { main tumor body }(p<0.0001 \text { ) and associated with } \\
\text { KRAS mutation. High expression of membranous } \\
\text { Trkb-independent adverse prognostic factor. } \\
\text { Inverse correlations between expression profile } \\
\text { of Trkb }(\mathrm{m}) \text { and Ki-67 as well as Caspase-3 (53) }\end{array}$ \\
\hline Cytokine signaling & $\begin{array}{l}\text { Akishima- } \\
\text { Fukusawa (71) }\end{array}$ & CXCL12, WTS & 165 Stage II-III CRC & Yes (Ueno) & $\begin{array}{l}\text { CXCL12-positive budding divided into high- and } \\
\text { low-grade, staining in the tumor divided into high } \\
\text { and low expression. Patients with high-grade } \\
\text { CXCL12 budding and high CXCL12 expression } \\
\text { had shorter survival than patients with low-grade } \\
\text { CXCL12 budding and low CXCL12 expression. } \\
\text { CXCL12 expression in buds independent adverse } \\
\text { prognostic factor in multivariate analysis } \\
\text { irrespective of budding grade }\end{array}$ \\
\hline
\end{tabular}


Table 1 | Continued

Biological role Reference

Markers and methods

Cohort

Budding

Results/relevance

assessed?

Scoring method

(reference)

\begin{tabular}{|c|c|c|c|c|c|}
\hline $\begin{array}{l}\text { Wnt signaling, } \\
\text { cell differentiation }\end{array}$ & Brabletz (76) & $\begin{array}{l}\text { B.catenin, Cdx2, laminin5 } \gamma 2 \text { WTS, } \\
\text { additional to cell culture experiments } \\
\text { and immunofluorescence }\end{array}$ & $45 \mathrm{CRC}$ cases, Stage n/a & No & $\begin{array}{l}\text { Cdx2 expression was lost in tumor buds but } \\
\text { re-expressed in metastases, cell culture } \\
\text { experiments demonstrate transient } \\
\text { transcriptional down-regulation of } \mathrm{Cd} 2 \mathrm{2} \text { triggered } \\
\text { by collagen type I }\end{array}$ \\
\hline $\begin{array}{l}\text { Stromal cell } \\
\text { interaction }\end{array}$ & Galvan (79) & $\begin{array}{l}\text { TWIST1 and TWIST2 } \\
\text { immunohistochemistry on } 2 \text { cohorts: } \\
\text { cohort } 1 \text { (multi-punch TMA) + } \\
\text { promoter methylation. Cohort 2: TMA } \\
\text { from pre-operative biopsies } \\
\text { (prognostic effects). } \\
\text { Immunohistochemistry for both } \\
\text { markers and promoter methylation in } \\
\text { six cell lines. LCM in one } \\
\text { tumor-budding high and one } \\
\text { tumor-budding low case }\end{array}$ & $\begin{array}{l}\text { Cohort 1: } 185 \text { Stage I-IV CRC, } \\
\text { Cohort 2: } 112 \text { Stage I-IV CRC }\end{array}$ & $\begin{array}{l}\text { Yes [cohort 1: } \\
\text { Karamitopoulou, cohort } \\
\text { 2: Zlobec (3)] }\end{array}$ & $\begin{array}{l}\text { TWIST } 1 \text { and } 2 \text { expression restricted to stromal } \\
\text { cells. Inverse correlation between TWIST1 protein } \\
\text { expression and methylation (Cohort 1) suggests } \\
\text { hypermethylation as a mechanism of TWIST1 } \\
\text { regulation. TWIST } 1 \text { and } 2 \text { protein expression } \\
\text { significantly correlated with low- and high-grade } \\
\text { budding phenotype. LCM of high-grade } \\
\text { tumor-budding case with positive TWIST1/2 } \\
\text { stroma and no methylation, inverse pattern in } \\
\text { low-grade tumor-budding case. TWIST1 (Cohort 2) } \\
\text { associated with adverse tumor features and } \\
\text { independent prognostic factor. }\end{array}$ \\
\hline $\begin{array}{l}\text { Stromal cell } \\
\text { interaction }\end{array}$ & Karagiannis (81) & $\begin{array}{l}\text { Bone morphogenic protein } \\
\text { antagonists HTRA3, FST and GREM1, } \\
\text { markers assessed in tumors and } \\
\text { cancer-associated fibroblasts, WTS }\end{array}$ & $\begin{array}{l}2 \text { cohorts: } 1: 30 \text { patients with } 10 \\
\text { each no, low and high-grade } \\
\text { budding. 2: } 219 \text { Stage II CRC }\end{array}$ & Yes (Ueno) & $\begin{array}{l}\text { HTRA3 staining in the epithelial tumor } \\
\text { component was differentially regulated between } \\
\text { areas with and without tumor-budding, correlation } \\
\text { between HETRA3 staining and the presence of } \\
\text { budding and with significantly increased } \\
\text { expression in tumor-budding cells themselves. } \\
\text { Epithelial HTRA3 expression-independent } \\
\text { adverse prognostic factor }\end{array}$ \\
\hline
\end{tabular}

WTS, whole tissue sections; LR, local recurrence; SAC, serrated adenocarcinomas; CAC, conventional adenocarcinomas; MMRd, mismatch repair deficient; MMRp, mismatch repair proficient; LCM, laser capture microdissection. 
inactive complex with CDK2, accounting for the apparently paradoxical co-upregulation of p16 and cyclin D1 (58). Indeed, tumor buds have been demonstrated to show cytoplasmic expression of p16 $(19,57)$. As a consequence, several studies have demonstrated the hypo-proliferative nature of the invasive front and tumor buds themselves using Ki-67 immunohistochemistry (30, 39, 45, 59).

As the hypo-proliferative nature of tumor buds is gaining recognition, it may be speculated that in order to survive migration through stroma, tumor buds must confer of essential survival mechanisms. In fact, single epithelial cells detached from the extracellular matrix are programed to undergo a certain form of cell death termed anoikis (60). In addition to their hypo-proliferative state, tumor buds have been demonstrated to be anti-apoptotic by their relative lack of immunoreactivity for caspase 3 (59), suggesting that tumor buds are able to resist anoikis.

\section{EMT-INDUCING PATHWAYS INVOLVING RAS/RAF AND RAS/MAPK SIGNALING}

Cancer cells frequently exploit growth factor signaling from the surrounding microenvironment (such as insulin growth factor, hepatocyte growth factor, epidermal growth factor, or placentalderived growth factor) to drive tumor progression (61-63). Wellstudied downstream pathways include PI3K-, NFкB-, Snail, and RAS-RAF-ERK-ZEB1 (Figure 1). For instance, as Snail controls ZEB1, a transcriptional repressor of E-cadherin (64); it is



FIGURE 1 | An example of tumor budding (single tumor cells and small clusters of up to five tumor cells detached from the main tumor body). These can be seen on $\mathrm{H} \& \mathrm{E}[(\mathbf{A})$, arrows] but are far more readily recognized on the pancytokeratin immunostain of the corresponding tumor area [(B), arrows]. not surprising that genes involved in growth factor signaling induce EMT.

The tumor suppressor gene RKIP has been linked to EMT on several levels, for one as inhibitor of the Ras-Raf-MEK-ERK signaling cascade at the level of Raf (65). In addition, RKIP modulates other signaling pathways including NFкB-Snail $(46,66)$. Several studies have demonstrated differential expression of RKIP in zones of colorectal cancer, with gradual loss of expression toward the tumor front $(33,67)$ and ability of RKIP expression to predict highgrade budding. RKIP was only rarely detected in tumor buds and in line with mechanistic EMT studies, loss of RKIP correlated with E-Cadherin negativity and nuclear translocation of NFKB. However, the prognostic significance of RKIP appears to be restricted to its expression in the tumor center, suggesting that other mechanisms may become increasingly important in the development of tumor-budding cells (67).

The neurotrophic tyrosine kinase receptor TrkB has been linked to EMT via RAS/MAPK-dependent Twist-Snail signaling and has been demonstrated to be a potent and specific suppressor of anoikis (47), which is supported by its overexpression in tumor buds (68). Additionally, KRAS-mutated colorectal cancers also overexpress $\operatorname{TrkB}$, in concordance with the known dependency on MAPK signaling on TrkB-induced EMT.

\section{CXCL12 (sdf-1)/CXCR4 PATHWAY}

Chemokines, integral for cell migration and trafficking, are widely expressed by cells of the lymphatic and hemopoietic systems. The chemokine CXCL12 binds to its receptor CXCL4, activating subsequent intracellular pathways involved in chemotaxis, cell survival, and gene transcription (69). As CXCR4 is expressed in cells in multiple organs including lymph nodes, lungs, and liver, epithelial tumor cells may take advantage of the principle of homing mechanisms to direct the metastasis of CXCL12-positive tumor cells to CXCR4 positive organs (70). CXCL12 can also stimulate the formation of capillary structures (48). CXCL12 expression in tumor buds was found to be correlated with liver metastases and was an independent prognostic marker (71).

\section{MARKERS OF INTESTINAL DIFFERENTIATION}

The homeobox transcription factor $\mathrm{Cdx} 2$ encodes a transcription factor specific to intestinal differentiation, which is essential for development and homeostasis of gut epithelium (72). Recent evidence also suggests that $\mathrm{Cdx} 2$ may play a substantial role in Wnt signaling as a tumor suppressor gene and therefore inhibit EMT. For instance, $\mathrm{Cdx} 2$ has been found to bind $\beta$-catenin, thus disrupting the $\beta$-catenin/TCF complex (73). Also, $\mathrm{Cdx} 2$ may inhibit the transcriptional activity of $\beta$-catenin through interaction with the protocadherin Mucdhl (74). Finally, Cdx2 enhances the function of E-cadherin by trafficking it to the cell membrane, thus restoring cell adhesion (75). As dedifferentiated cancer cells, it is not surprising that tumor buds lack expression of Cdx2 (76). However, the fact that most colorectal cancers that diffusely express $\mathrm{Cdx} 2$ also do so in their metastases (as the marker may be used diagnostically for cancers of unknown primary as a marker of intestinal differentiation) supports the notion of tumor redifferentiation and reversibility of EMT at metastatic sites. 
Few studies have examined the expression of other markers of epithelial differentiation in tumor buds. For instance, Harbaum et al (30) demonstrated absence of the intestinal-type mucin Muc2 and overexpression of cytokeratin 7, a simple intermediate keratin filament, at the invasive front and strikingly in tumor buds. This finding is intriguing since expression of cytokeratin 7 is relatively infrequent in primary colorectal carcinoma (77), and because intermediate filaments are traditionally known to support cell-cell or cell-matrix adhesions in epithelial cells. However, recent evidence suggests that keratin filaments may contribute to a higher degree of cellular plasticity than originally assumed (78) and it may be postulated that surrounding biochemical and mechanical stimulation in the tumor microenvironment could influence the cytoskeletal protein composition.

\section{STROMAL-EPITHELIAL INTERACTION IN THE TUMOR MICROENVIRONMENT}

It has also been postulated that signals derived from surrounding mesenchymal cells in the tumor microenvironment may play a significant role in facilitating a pro-budding phenotype $(50,79)$. For instance, immunohistochemical expression of TWIST1 and TWIST2, known activators of EMT, was significantly positively correlated with a tumor-budding phenotype (both low-grade and high-grade budding), yet their expression was virtually restricted to stromal cells in the tumor microenvironment. Moreover, in high-grade budding cancers an inverse correlation between TWIST1 methylation and stromal protein expression was observed, suggesting hypermethylation as a mechanism of TWIST1 regulation (79). TWIST1 has previously been demonstrated to be expressed in neoplastic stromal cells. These cells were shown to be neoplastic, demonstrating the same neoplastic aberrations as the tumor itself, indicating that EMT had indeed taken place with cells having acquired a fully mesenchymal phenotype (80).

The interplay between epithelial and stromal components has also been underlined by studies examining bone morphogenetic protein (BMP) antagonists $(51,81)$, hypothesizing that CRC cells in the tumor microenvironment can only flourish in a milieu devoid of BMP signaling, this was characterized immunohistochemically by a shift in HTRA3 expression patterns (decreased stromal staining and increased epithelial staining).

\section{CONCLUSION}

Tumor budding is thought to represent the morphological correlate of EMT in colorectal cancers and has been strongly linked to adverse clinicopathological features and poor overall and diseasefree patient survival. These consistent associations indicate that tumor budding has a strong value as a prognostic indicator, and it has been proposed that budding should be an integrated category in pathology reports (82).

In an attempt to contribute to our understanding of tumor buds, previous studies have mainly immunohistochemistry to discriminate properties unique to tumor-budding cells. The main reason for this is that immunohistochemistry enables the actual identification of tumor buds for evaluation. To our knowledge, there is currently no method of extracting tumor buds from fresh tumor tissue, presenting huge hurdles for molecular studies specifically geared at tumor buds. Therefore, our understanding of the biology of tumor buds is essentially restricted to protein expresssion profiles (as visualized in Figure 2), and a few studies, which have used mRNA in situ hybridization. Immunohistochemistry as

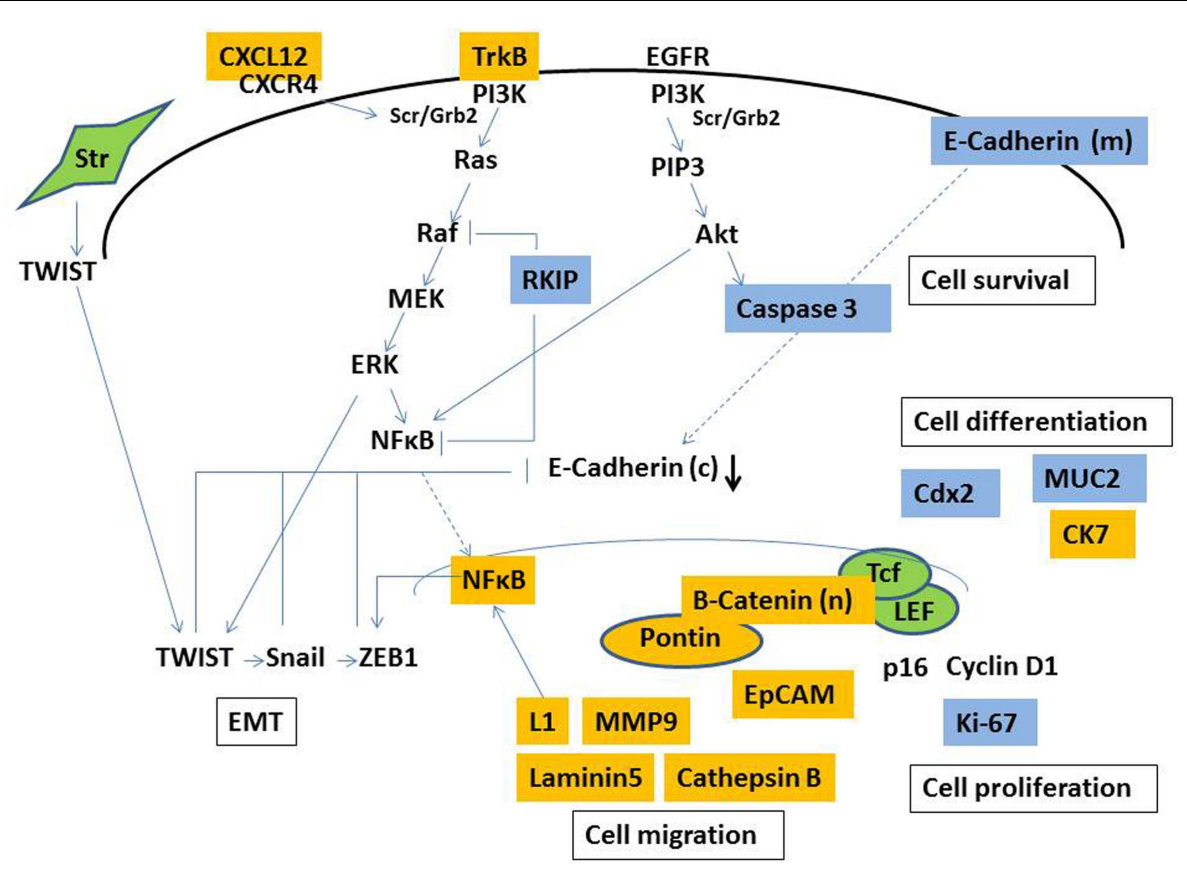

FIGURE 2 | Simplified illustration of molecular pathways involved in the formation of tumor budding. Markers demonstrated to be overexpressed (yellow) and underexpressed (blue) in tumor buds by immunohistochemistry. Str, stromal cell, (c), cytoplasmic, (m) membranous, (n) nuclear. 
a semi-quantitative method may be especially prone to subjectivity, and staining intensity greatly depends on laboratory methods (83). Such issues may contribute to difficulties in reproducibility and the consistency of results. Not all proteins differentially expressed in tumor buds appear to have significant prognostic relevance, which may be at least in part explained by the timing of certain events in the process of carcinogenesis and the accumulation of different simultaneous molecular occurrences, of which our knowledge is limited.

Therefore, although the molecular background of colorectal cancers appears to play an important role in budding, much remains to be investigated in terms of genetic profiles of tumor buds and how various molecular pathways are taken advantage of by these cells to maintain their malignant phenotype and drive tumor progression. Novel areas of interest include the interaction of tumor buds with cancer-associated fibroblasts and inflammatory cells in the tumor microenvironment (84) and the evasion of anoikis. Taken together, and based on growing evidence that tumor buds may be targetable structures (15), our understanding of these mechanisms will be crucial for the development of future therapies aimed at the destruction of tumor buds.

\section{REFERENCES}

1. Kalluri R, Weinberg RA. The basics of epithelial-mesenchymal transition. J Clin Invest (2009) 119:1420-8. doi:10.1172/JCI39104

2. Thiery JP, Acloque H, Huang RY, Nieto MA. Epithelial-mesenchymal transitions in development and disease. Cell (2009) 139:871-90. doi:10.1016/j.cell. 2009.11.007

3. Zlobec I, Hadrich M, Dawson H, Koelzer VH, Borner M, Mallaev M, et al. Intratumoural budding (ITB) in preoperative biopsies predicts the presence of lymph node and distant metastases in colon and rectal cancer patients. Br J Cancer (2014) 110:1008-13. doi:10.1038/bjc.2013.797

4. Prall F. Tumour budding in colorectal carcinoma. Histopathology (2007) 50:151-62. doi:10.1111/j.1365-2559.2006.02551.x

5. Mitrovic B, Schaeffer DF, Riddell RH, Kirsch R. Tumor budding in colorectal carcinoma: time to take notice. Mod Pathol (2012) 25:1315-25. doi:10.1038/ modpathol.2012.94

6. Okuyama T, Nakamura T, Yamaguchi M. Budding is useful to select highrisk patients in stage II well-differentiated or moderately differentiated colon adenocarcinoma. Dis Colon Rectum (2003) 46:1400-6. doi:10.1007/s10350-0046757-0

7. Tanaka M, Hashiguchi Y, Ueno H, Hase K, Mochizuki H. Tumor budding at the invasive margin can predict patients at high risk of recurrence after curative surgery for stage II, T3 Colon Cancer. Dis Colon Rectum (2003) 46:1054-9. doi:10.1007/s10350-004-7280-z

8. Hase K, Shatney C, Johnson D, Trollope M, Vierra M. Prognostic value of tumor "budding" in patients with colorectal cancer. Dis Colon Rectum (1993) 36:627-35. doi:10.1007/BF02238588

9. Ueno H, Murphy J, Jass JR, Mochizuki H, Talbot IC. Tumour 'budding' as an index to estimate the potential of aggressiveness in rectal cancer. Histopathology (2002) 40:127-32. doi:10.1046/j.1365-2559.2002.01324.X

10. Ishikawa Y, Akishima-Fukasawa Y, Ito K, Akasaka Y, Yokoo T, Ishii T, et al. Group for cancer biological, histopathologic determinants of regional lymph node metastasis in early colorectal cancer. Cancer (2008) 112:924-33. doi:10.1002/ cncr. 23248

11. Nakamura T, Mitomi H, Kikuchi S, Ohtani Y, Sato K. Evaluation of the usefulness of tumor budding on the prediction of metastasis to the lung and liver after curative excision of colorectal cancer. Hepatogastroenterology (2005) 52:1432-5.

12. Wang LM, Kevans D, Mulcahy H, O'Sullivan J, Fennelly D, Hyland J, et al. Tumor budding is a strong and reproducible prognostic marker in T3N0 colorectal cancer. Am J Surg Pathol (2009) 33:134-41. doi:10.1097/PAS.0b013e318184cd55
13. Gabbert H, Wagner R, Moll R, Gerharz CD. Tumor dedifferentiation: an important step in tumor invasion. Clin Exp Metastasis (1985) 3:257-79. doi:10.1007/ BF01585081

14. Horcic M, Koelzer VH, Karamitopoulou E, Terracciano L, Puppa G, Zlobec I, et al. Tumor budding score based on 10 high-power fields is a promising basis for a standardized prognostic scoring system in stage II colorectal cancer. Hum Pathol (2013) 44:697-705. doi:10.1016/j.humpath.2012.07.026

15. Zlobec I, Lugli A. Epithelial mesenchymal transition and tumor budding in aggressive colorectal cancer: tumor budding as oncotarget. Oncotarget (2010) 1:651-61.

16. N. Cancer Genome Atlas. Comprehensive molecular characterization of human colon and rectal cancer. Nature (2012) 487:330-7. doi:10.1038/nature11252

17. Chen D, Huang JF, Liu K, Zhang LQ, Yang Z, Chuai ZR, et al. BRAFV600E mutation and its association with clinicopathological features of colorectal cancer: a systematic review and meta-analysis. PLoS One (2014) 9:e90607. doi:10.1371/journal.pone.0090607

18. Morikawa T, Kuchiba A, Qian ZR, Mino-Kenudson M, Hornick JL, Yamauchi $\mathrm{M}$, et al. Prognostic significance and molecular associations of tumor growth pattern in colorectal cancer. Ann Surg Oncol (2012) 19:1944-53. doi:10.1245/ s10434-011-2174-5

19. Jass JR, Barker M, Fraser L, Walsh MD, Whitehall VL, Gabrielli B, et al. APC mutation and tumour budding in colorectal cancer. J Clin Pathol (2003) 56:69-73. doi:10.1136/jcp.56.1.69

20. Zlobec I, Bihl MP, Foerster A, Rufle A, Lugli A. The impact of CpG island methylator phenotype and microsatellite instability on tumour budding in colorectal cancer. Histopathology (2012) 61:777-87. doi:10.1111/j.1365-2559.2012. 04273.x

21. Shinto E, Baker K, Tsuda H, Mochizuki H, Ueno H, Matsubara O, et al. Tumor buds show reduced expression of laminin-5 gamma 2 chain in DNA mismatch repair deficient colorectal cancer. Dis Colon Rectum (2006) 49:1193-202. doi:10.1007/s10350-006-0568-4

22. Garcia-Solano J, Conesa-Zamora P, Trujillo-Santos J, Torres-Moreno D, Makinen MJ, Perez-Guillermo M. Immunohistochemical expression profile of beta-catenin, E-cadherin, P-cadherin, laminin-5gamma2 chain, and SMAD4 in colorectal serrated adenocarcinoma. Hum Pathol (2012) 43:1094-102. doi:10. 1016/j.humpath.2011.08.020

23. Kang GH. Four molecular subtypes of colorectal cancer and their precursor lesions. Arch Pathol Lab Med (2011) 135:698-703. doi:10.1043/2010-0523-RA.1

24. Lochhead P, Kuchiba A, Imamura Y, Liao X, Yamauchi M, Nishihara R, et al. Microsatellite instability and BRAF mutation testing in colorectal cancer prognostication. J Natl Cancer Inst (2013) 105:1151-6. doi:10.1093/jnci/djt173

25. Gosens MJ, van Kempen LC, van de Velde CJ, van Krieken JH, Nagtegaal ID. Loss of membranous Ep-CAM in budding colorectal carcinoma cells. Mod Pathol (2007) 20:221-32. doi:10.1038/modpathol.3800733

26. Brabletz T, Hlubek F, Spaderna S, Schmalhofer O, Hiendlmeyer E, Jung A, et al. Invasion and metastasis in colorectal cancer: epithelial-mesenchymal transition, mesenchymal-epithelial transition, stem cells and beta-catenin. Cells Tissues Organs (2005) 179:56-65. doi:10.1159/000084509

27. Brabletz T, Jung A, Hermann K, Gunther K, Hohenberger W, Kirchner T. Nuclear overexpression of the oncoprotein beta-catenin in colorectal cancer is localized predominantly at the invasion front. Pathol Res Pract (1998) 194:701-4. doi:10.1016/S0344-0338(98)80129-5

28. El-Bahrawy MA, Poulsom R, Jeffery R, Talbot I, Alison MR. The expression of E-cadherin and catenins in sporadic colorectal carcinoma. Hum Pathol (2001) 32:1216-24. doi:10.1053/hupa.2001.28948

29. Lauscher JC, Loddenkemper C, Kosel L, Grone J, Buhr HJ, Huber O. Increased pontin expression in human colorectal cancer tissue. Hum Pathol (2007) 38:978-85. doi:10.1016/j.humpath.2007.01.005

30. Harbaum L, Pollheimer MJ, Kornprat P, Lindtner RA, Schlemmer A, Rehak $\mathrm{P}$, et al. Keratin 7 expression in colorectal cancer - freak of nature or significant finding? Histopathology (2011) 59:225-34. doi:10.1111/j.1365-2559.2011. 03694.x

31. Brabletz T, Jung A, Reu S, Porzner M, Hlubek F, Kunz-Schughart LA, et al. Variable beta-catenin expression in colorectal cancers indicates tumor progression driven by the tumor environment. Proc Natl Acad Sci USA (2001) 98:10356-61. doi:10.1073/pnas.171610498

32. Horkko TT, Klintrup K, Makinen JM, Napankangas JB, Tuominen HJ, Makela $\mathrm{J}$, et al. Budding invasive margin and prognosis in colorectal cancer - no 
direct association with beta-catenin expression. Eur J Cancer (2006) 42:964-71. doi:10.1016/j.ejca.2006.01.017

33. Karamitopoulou E, Zlobec I, Panayiotides I, Patsouris ES, Peros G, Rallis G, et al. Systematic analysis of proteins from different signaling pathways in the tumor center and the invasive front of colorectal cancer. Hum Pathol (2011) 42:1888-96. doi:10.1016/j.humpath.2010.06.020

34. Jass JR, Young J, Leggett BA. Evolution of colorectal cancer: change of pace and change of direction. J Gastroenterol Hepatol (2002) 17:17-26. doi:10.1046/ j.1440-1746.2002.02635.x

35. Karamitopoulou E, Zlobec I, Kolzer V, Kondi-Pafiti A, Patsouris ES, Gennatas $\mathrm{K}$, et al. Proposal for a 10-high-power-fields scoring method for the assessment of tumor budding in colorectal cancer. Mod Pathol (2013) 26:295-301. doi:10.1038/modpathol.2012.155

36. Prall F, Nizze H, Barten M. Tumour budding as prognostic factor in stage I/II colorectal carcinoma. Histopathology (2005) 47:17-24. doi:10.1111/j.1365-2559. 2005.02161.x

37. Morodomi T, Isomoto H, Shirouzu K, Kakegawa K, Irie K, Morimatsu M. An index for estimating the probability of lymph node metastasis in rectal cancers. Lymph node metastasis and the histopathology of actively invasive regions of cancer. Cancer (1989) 63:539-43. doi:10.1002/1097-0142(19890201)63:3<539: :AID-CNCR2820630323>3.0.CO;2-S

38. Guzinska-Ustymowicz K. MMP-9 and cathepsin B expression in tumor budding as an indicator of a more aggressive phenotype of colorectal cancer (CRC). Anticancer Res (2006) 26:1589-94.

39. Rubio CA. Arrest of cell proliferation in budding tumor cells ahead of the invading edge of colonic carcinomas. A preliminary report. Anticancer Res (2008) 28:2417-20

40. Sordat I, Rousselle P, Chaubert P, Petermann O, Aberdam D, Bosman FT, et al. Tumor cell budding and laminin-5 expression in colorectal carcinoma can be modulated by the tissue micro-environment. Int J Cancer (2000) 88:708-17. doi:10.1002/1097-0215(20001201)88:5<708::AID-IJC5>3.0.CO;2-J

41. Munz M, Baeuerle PA, Gires O. The emerging role of EpCAM in cancer and stem cell signaling. Cancer Res (2009) 69:5627-9. doi:10.1158/0008-5472.CAN09-0654

42. Gavert N, Conacci-Sorrell M, Gast D, Schneider A, Altevogt P, Brabletz T, et al. L1, a novel target of beta-catenin signaling, transforms cells and is expressed at the invasive front of colon cancers. J Cell Biol (2005) 168:633-42. doi: $10.1083 /$ jcb. 200408051

43. Fan F, Samuel S, Evans KW, Lu J, Xia L, Zhou Y, et al. Overexpression of snail induces epithelial-mesenchymal transition and a cancer stem cell-like phenotype in human colorectal cancer cells. Cancer Med (2012) 1:5-16. doi:10.1002/cam4.4

44. Horst D, Kriegl L, Engel J, Kirchner T, Jung A. Prognostic significance of the cancer stem cell markers CD133, CD44, and CD166 in colorectal cancer. Cancer Invest (2009) 27:844-50. doi:10.1080/07357900902744502

45. Jung A, Schrauder M, Oswald U, Knoll C, Sellberg P, Palmqvist R, et al. The invasion front of human colorectal adenocarcinomas shows co-localization of nuclear beta-catenin, cyclin D1, and p16INK4A and is a region of low proliferation. Am J Pathol (2001) 159:1613-7. doi:10.1016/S0002-9440(10)63007-6

46. Escara-Wilke J, Yeung K, Keller ET. Raf kinase inhibitor protein (RKIP) in cancer. Cancer Metastasis Rev (2012) 31:615-20. doi:10.1007/s10555-012-9365-9

47. Smit MA, Geiger TR, Song JY, Gitelman I, Peeper DS. A Twist-Snail axis critical for TrkB-induced epithelial-mesenchymal transition-like transformation, anoikis resistance, and metastasis. Mol Cell Biol (2009) 29:3722-37. doi:10.1128/MCB.01164-08

48. Petit I, Jin D, Rafii S. The SDF-1-CXCR4 signaling pathway: a molecular hub modulating neo-angiogenesis. Trends Immunol (2007) 28:299-307. doi:10.1016/j.it.2007.05.007

49. Hostettler L, Zlobec I, Terracciano L, Lugli A. ABCG5-positivity in tumor buds is an indicator of poor prognosis in node-negative colorectal cancer patients. World J Gastroenterol (2010) 16:732-9. doi:10.3748/wjg.v16.i6.732

50. Rizzi C, Cataldi P, Iop A, Isola M, Sgarra R, Manfioletti G, et al. The expression of the high-mobility group A2 protein in colorectal cancer and surrounding fibroblasts is linked to tumor invasiveness. Hum Pathol (2013) 44:122-32. doi:10.1016/j.humpath.2012.05.001

51. Karagiannis GS, Berk A, Dimitromanolakis A, Diamandis EP. Enrichment map profiling of the cancer invasion front suggests regulation of colorectal cancer progression by the bone morphogenetic protein antagonist, gremlin-1. Mol Oncol (2013) 7:826-39. doi:10.1016/j.molonc.2013.04.002
52. Gavert N, Ben-Shmuel A, Lemmon V, Brabletz T, Ben-Ze'ev A. Nuclear factorkappaB signaling and ezrin are essential for L1-mediated metastasis of colon cancer cells. J Cell Sci (2010) 123:2135-43. doi:10.1242/jcs.069542

53. Wu Y, Deng J, Rychahou PG, Qiu S, Evers BM, Zhou BP. Stabilization of snail by NF-kappaB is required for inflammation-induced cell migration and invasion. Cancer Cell (2009) 15:416-28. doi:10.1016/j.ccr.2009.03.016

54. Zeuner A, Todaro M, Stassi G, De Maria R. Colorectal cancer stem cells: from the crypt to the clinic. Cell Stem Cell (2014) 15:692-705. doi:10.1016/j.stem.2014. 11.012

55. Findlay VJ, Wang C, Watson DK, Camp ER. Epithelial-to-mesenchymal transition and the cancer stem cell phenotype: insights from cancer biology with therapeutic implications for colorectal cancer. Cancer Gene Ther (2014) 21:181-7. doi:10.1038/cgt.2014.15

56. Kleist B, Xu L, Li G, Kersten C. Expression of the adult intestinal stem cell marker Lgr5 in the metastatic cascade of colorectal cancer. Int J Clin Exp Pathol (2011) 4:327-35.

57. Brabletz T. To differentiate or not - routes towards metastasis. Nat Rev Cancer (2012) 12:425-36. doi:10.1038/nrc3265

58. Sweeney KJ, Sarcevic B, Sutherland RL, Musgrove EA. Cyclin D2 activates Cdk2 in preference to Cdk4 in human breast epithelial cells. Oncogene (1997) 14:1329-40. doi:10.1038/sj.onc.1200951

59. Dawson H, Koelzer VH, Karamitopoulou E, Economou M, Hammer C, Muller $\mathrm{DE}$, et al. The apoptotic and proliferation rate of tumour budding cells in colorectal cancer outlines a heterogeneous population of cells with various impacts on clinical outcome. Histopathology (2014) 64:577-84. doi:10.1111/his.12294

60. Guadamillas MC, Cerezo A, Del Pozo MA. Overcoming anoikis - pathways to anchorage-independent growth in cancer. J Cell Sci (2011) 124:3189-97. doi: $10.1242 /$ jcs. 072165

61. Spano JP, Fagard R, Soria JC, Rixe O, Khayat D, Milano G. Epidermal growth factor receptor signaling in colorectal cancer: preclinical data and therapeutic perspectives. Ann Oncol (2005) 16:189-94. doi:10.1093/annonc/mdi057

62. Capdevila J, Carrato A, Tabernero J, Grande E. What could Nintedanib (BIBF 1120), a triple inhibitor of VEGFR, PDGFR, and FGFR, add to the current treatment options for patients with metastatic colorectal cancer? Crit Rev Oncol Hematol (2014) 92(2):83-106. doi:10.1016/j.critrevonc.2014.05.004

63. Malaguarnera R, Belfiore A. The emerging role of insulin and insulin-like growth factor signaling in cancer stem cells. Front Endocrinol (Lausanne) (2014) 5:10. doi:10.3389/fendo.2014.00010

64. Schmalhofer O, Brabletz S, Brabletz T. E-cadherin, beta-catenin, and ZEB1 in malignant progression of cancer. Cancer Metastasis Rev (2009) 28:151-66. doi:10.1007/s10555-008-9179-y

65. Yeung K, Seitz T, Li S, Janosch P, McFerran B, Kaiser C, et al. Suppression of Raf-1 kinase activity and MAP kinase signalling by RKIP. Nature (1999) 401:173-7. doi: $10.1038 / 43686$

66. Wu K, Bonavida B. The activated NF-kappaB-Snail-RKIP circuitry in cancer regulates both the metastatic cascade and resistance to apoptosis by cytotoxic drugs. Crit Rev Immunol (2009) 29:241-54. doi:10.1615/CritRevImmunol.v29.i3.40

67. Koelzer VH, Karamitopoulou E, Dawson H, Kondi-Pafiti A, Zlobec I, Lugli A. Geographic analysis of RKIP expression and its clinical relevance in colorectal cancer. Br J Cancer (2013) 108:2088-96. doi:10.1038/bjc.2013.197

68. Dawson H, Grundmann S, Koelzer VH, Galvan JA, Kirsch R, Karamitopoulou E, et al. Tyrosine kinase receptor B (TrkB) expression in colorectal cancers highlights anoikis resistance as a survival mechanism of tumour budding cells. Histopathology (2014). doi:10.1111/his.12603

69. Cojoc M, Peitzsch C, Trautmann F, Polishchuk L, Telegeev GD, Dubrovska A. Emerging targets in cancer management: role of the CXCL12/CXCR4 axis. OncoTargets Ther (2013) 6:1347-61. doi:10.2147/OTT.S36109

70. Teicher BA, Fricker SP. CXCL12 (SDF-1)/CXCR4 pathway in cancer. Clin Cancer Res (2010) 16:2927-31. doi:10.1158/1078-0432.CCR-09-2329

71. Akishima-Fukasawa Y, Nakanishi Y, Ino Y, Moriya Y, Kanai Y, Hirohashi S. Prognostic significance of CXCL12 expression in patients with colorectal carcinoma. Am J Clin Pathol (2009) 132:202-10. doi:10.1309/AJCPK35VZJEWCUTL

72. Lorentz O, Duluc I, Arcangelis AD, Simon-Assmann P, Kedinger M, Freund JN. Key role of the Cdx2 homeobox gene in extracellular matrix-mediated intestinal cell differentiation. J Cell Biol (1997) 139:1553-65. doi:10.1083/jcb. 139.6.1553

73. Guo RJ, Funakoshi S, Lee HH, Kong J, Lynch JP. The intestine-specific transcription factor $\mathrm{Cdx} 2$ inhibits beta-catenin/TCF transcriptional activity 
by disrupting the beta-catenin-TCF protein complex. Carcinogenesis (2010) 31:159-66. doi:10.1093/carcin/bgp213

74. Hinkel I, Duluc I, Martin E, Guenot D, Freund JN, Gross I. Cdx2 controls expression of the protocadherin Mucdhl, an inhibitor of growth and betacatenin activity in colon cancer cells. Gastroenterology (2012) 142:875-85.e3. doi:10.1053/j.gastro.2011.12.037

75. Funakoshi S, Kong J, Crissey MA, Dang L, Dang D, Lynch JP. Intestine-specific transcription factor $\mathrm{Cdx} 2$ induces E-cadherin function by enhancing the trafficking of E-cadherin to the cell membrane. Am J Physiol Gastrointest Liver Physiol (2010) 299:G1054-67. doi:10.1152/ajpgi.00297.2010

76. Brabletz T, Spaderna S, Kolb J, Hlubek F, Faller G, Bruns CJ, et al. Downregulation of the homeodomain factor $\mathrm{Cdx} 2$ in colorectal cancer by collagen type I: an active role for the tumor environment in malignant tumor progression. Cancer Res (2004) 64:6973-7. doi:10.1158/0008-5472.CAN-04-1132

77. Bayrak R, Yenidunya S, Haltas H. Cytokeratin 7 and cytokeratin 20 expression in colorectal adenocarcinomas. Pathol Res Pract (2011) 207:156-60. doi:10.1016/j.prp.2010.12.005

78. Helfand BT, Chang L, Goldman RD. Intermediate filaments are dynamic and motile elements of cellular architecture. J Cell Sci (2004) 117:133-41. doi:10.1242/jcs.00936

79. Galvan JA, Helbling M, Koelzer VH, Tschan MP, Berger MD, Hadrich M, et al. TWIST1 and TWIST2 promoter methylation and protein expression in tumor stroma influence the epithelial-mesenchymal transition-like tumor budding phenotype in colorectal cancer. Oncotarget (2015) 20:874-85.

80. Celesti G, Di Caro G, Bianchi P, Grizzi F, Basso G, Marchesi F, et al. Presence of Twist1-positive neoplastic cells in the stroma of chromosomeunstable colorectal tumors. Gastroenterology (2013) 145:647-57.e15. doi:10. 1053/j.gastro.2013.05.011
81. Karagiannis GS, Treacy A, Messenger D, Grin A, Kirsch R, Riddell RH, et al. Expression patterns of bone morphogenetic protein antagonists in colorectal cancer desmoplastic invasion fronts. Mol Oncol (2014) 8:1240-52. doi:10.1016/ j.molonc.2014.04.004

82. Lugli A, Karamitopoulou E, Zlobec I. Tumour budding: a promising parameter in colorectal cancer. Br J Cancer (2012) 106:1713-7. doi:10.1038/bjc.2012.127

83. Zlobec I, Terracciano L, Jass JR, Lugli A. Value of staining intensity in the interpretation of immunohistochemistry for tumor markers in colorectal cancer. Virchows Arch (2007) 451:763-9. doi:10.1007/s00428-007-0466-8

84. Zlobec I, Lugli A. Invasive front of colorectal cancer: dynamic interface of pro/anti-tumor factors. World J Gastroenterol (2009) 15:5898-906. doi:10.3748/wjg. 15.5898

Conflict of Interest Statement: The authors declare that the research was conducted in the absence of any commercial or financial relationships that could be construed as a potential conflict of interest.

Received: 12 January 2015; paper pending published: 04 February 2015; accepted: 25 February 2015; published online: 10 March 2015.

Citation: Dawson H and Lugli A (2015) Molecular and pathogenetic aspects of tumor budding in colorectal cancer. Front. Med. 2:11. doi: 10.3389/fmed.2015.00011

This article was submitted to Pathology, a section of the journal Frontiers in Medicine. Copyright (c) 2015 Dawson and Lugli. This is an open-access article distributed under the terms of the Creative Commons Attribution License (CC BY). The use, distribution or reproduction in other forums is permitted, provided the original author (s) or licensor are credited and that the original publication in this journal is cited, in accordance with accepted academic practice. No use, distribution or reproduction is permitted which does not comply with these terms. 